Article

\title{
Metallic Nanoparticles Obtained via "Green" Synthesis as a Platform for Biosensor Construction
}

\author{
Galina Z. Gayda ${ }^{1, *}$, Olha M. Demkiv ${ }^{1,2}{ }^{\circledR}$, Nataliya Ye. Stasyuk ${ }^{1}\left(\mathbb{D}\right.$, Roman Ya. Serkiz $^{1}$, \\ Maksym D. Lootsik ${ }^{1}$, Abdelhamid Errachid ${ }^{3}$, Mykhailo V. Gonchar ${ }^{1,2}$ and \\ Marina Nisnevitch $4, *$ (D) \\ 1 Institute of Cell Biology, National Academy of Sciences of Ukraine, Drahomanov Street 14/16, 79005 Lviv, \\ Ukraine; demkiv@yahoo.com (O.M.D.); stasuk_natalia@ukr.net (N.Y.S.); rserkiz@gmail.com (R.Y.S.); \\ lootsik@cellbiol.lviv.ua (M.D.L.); gonchar@cellbiol.lviv.ua or mykhailo1952@gmail.com (M.V.G.) \\ 2 Faculty of Biology, Drohobych Ivan Franko State Pedagogical University, 82100 Drohobych, Ukraine \\ 3 Institute of Analytical Sciences, UMR 5280, CNRS, Université Claude Bernard Lyon 1, ENS Lyon-5, \\ 5 rue de la Doua, F-69100 Villeurbanne, France; abdelhamid.errachid-el-salhi@univ-lyon1.fr \\ 4 Department of Chemical Engineering, Biotechnology and Materials, Ariel University, Ariel 4070000, Israel \\ * Correspondence: galina.gayda@gmail.com (G.Z.G.); marinan@ariel.ac.il (M.N.); \\ Tel.: +380-226-2144 (G.Z.G.); +972-3914-3042 (M.N.)
}

Received: 30 December 2018; Accepted: 14 February 2019; Published: 19 February 2019

\begin{abstract}
Novel nanomaterials, including metallic nanoparticles obtained via green synthesis (gNPs), have a great potential for application in biotechnology, industry and medicine. The special role of gNPs is related to antibacterial agents, fluorescent markers and carriers for drug delivery. However, application of gNPs for construction of amperometric biosensors (ABSs) is not well documented. The aim of the current research was to study potential advantages of using gNPs in biosensorics. The extracellular metabolites of the yeast Ogataea polymorpha were used as reducing agents for obtaining gNPs from the corresponding inorganic ions. Several gNPs were synthesized, characterized and tested as enzyme carriers on the surface of graphite electrodes (GEs). The most effective were Pd-based gNPs (gPdNPs), and these were studied further and applied for construction of laccase- and alcohol oxidase (AO)-based ABSs. AO/GE, AO-gPdNPs/GE, laccase/GE and laccase-gPdNPs/GE were obtained, and their analytical characteristics were studied. Both gPdNPs-modified ABSs were found to have broader linear ranges and higher storage stabilities than control electrodes, although they are less sensitive toward corresponding substrates. We thus conclude that gPdNPs may be promising for construction of ABSs for enzymes with very high affinities to their substrates.
\end{abstract}

Keywords: green synthesis; metallic nanoparticles; extracellular metabolites; yeast Ogataea polymorpha; laccase; alcohol oxidase; amperometric biosensors

\section{Introduction}

Green synthesis of metallic nanoparticles (NPs) offers better manipulation, stabilization and control over crystal growth due to slower kinetics. Furthermore, green synthesis processes are rapid, eco-friendly and cost-effective [1-3]. Metallic NPs consisting of one metal, metal oxides or a composite of several metals play a significant role in nanotechnology due to their potential utilization in industry and medicine [3-7]. NPs of noble metals possess low cytotoxicity, enable easy modification of their surfaces, have straightforward synthesis processes and excellent biocompatibility [8-10]. Such advantages make metallic NPs obtained by green synthesis (gNPs) prospective for applications in biological analysis, drug delivery and imaging, environmental monitoring, industrial catalysis and electronic devices [11-19]. A special role of these gNPs is related to antimicrobial and antibiofilm agents [19-25]. 
Many plants [11,12,21,24-26], algae [4], microorganisms [1,3,7-10,14,18,23,27-30], as well as redox-imbalanced mammalian cells and systems [31] are known to produce nanostructured mineral crystals and metallic NPs with properties similar to chemically-synthesized materials. Biological agents, including polysaccharides, polypeptides, DNA, enzymes secreted by cells [24,32-41] and purified enzymes [42,43] are able to reduce noble metal ions to gain metallic NPs. Besides the practical aim of gNPs production, investigations on the green synthesis processes will be useful for elucidating the mechanisms of cells' responses to stress caused by metal ions.

In many studies, the size and morphology of gNPs are considered as their basic parameters. Scanning electron microscopy (SEM) can afford information on the size, distribution and shape of the gNPs. However, the drying and contrasting processes alter the characteristics of the tested NPs and lead to imaging faults or artifacts [32]. Transmission electron microscopy (TEM) is a high-tech approach in the characterization of gNPs, and is more powerful and competitive than SEM. It can be used to determine the particle size, dispersion and aggregation in aqueous environment with a high spatial resolution that can reveal details of crystal structure. Since many gNPs are irregular in shape and exhibit a tendency to form large particles, it is difficult to conclude definitely whether their final form was caused by polydispersity or agglomeration. The most suitable method for characterization of gNPs is a dynamic light scattering (DLS) technique, which can provide data on sphere hydrodynamic diameters of homogeneous NPs in an aqueous phase [44]. However, this method cannot provide information on particles with a heterogeneous size distribution. Therefore, the diversity and ambiguity of gNPs are the reason why it is necessary to use multiple techniques, for instance a combination of TEM and DLS, for valid characterization of gNPs [32,44].

The exact mechanism of gNP synthesis using biological agents has not been elucidated to date. However, it has been suggested that various biomolecules are involved in this process [24,38-48]. Capping and stabilizing agents (polysaccharides, polypeptides and other bioorganic compounds) prevent the gNPs from further growth and agglomeration in resulted colloidal solution [45-51]. Extracellular synthesis of gNPs usually occurs when microbial cells secrete reductive enzymes on the surface of cell wall or outside the cell [43,45-48]. This process mediated through different enzymes, including hydrogenases [40], nitrate reductase [48], phenol-oxidizing enzymes (laccases, tyrosinases, and Mn-peroxidases) [43], as well as adhesins [49], has been described. In addition to the reducing extracellular metabolites, the cell wall of microorganisms seems to play an important role in the intracellular synthesis of NPs [8,27,44-47]. It interacts electrostatically with metal ions and traps them in the process. The reducing agents and enzymes reduce the metal ions. Finally, formation of gNPs takes place.

We discovered the phenomenon of extracellular bioreduction of $\mathrm{Cr}(\mathrm{VI})$ through $\mathrm{Cr}(\mathrm{V})$ to $\mathrm{Cr}(\mathrm{III})$ by some yeasts, including baker's yeast as well as non-conventional yeasts (Candida guilliermondii, Ogataea polymorpha, etc.) [52-55]. The soluble stable green biocomplexes $\left(\mathrm{gCr}_{2} \mathrm{O}_{3} \mathrm{NPs}\right)$ generated outside the yeast cells were isolated. Methods for isolating the generated $\mathrm{gCr}_{2} \mathrm{O}_{3} \mathrm{NPs}$ were developed, namely freezing-thawing, precipitation with acetone, column chromatography, electrophoresis in native PAG, filtration, dialysis and others [55]. Yeast extracellular metabolites were shown to be responsible for $\mathrm{Cr}(\mathrm{VI})$ reduction $[54,55]$.

In our previous study, we reported on green synthesis of AuNPs by the yeast Ogataea polymorpha [56]. BioAuNPs of different sizes $(20-40 \mathrm{~nm})$ and shapes, from triangular nanoprisms to nearly spherical and hexagonal ones, were obtained using both the yeast culture and extracellular metabolites of the culture liquid after removal of the cells. The optimal conditions (inorganic ion concentrations and incubation times) required for extracellular synthesis of AuNPs were chosen. The size, structure and fluorescence of the NPs were characterized using scanning, atomic force, transmission and fluorescence microscopy [56].

The aim of the current research was to obtain various NPs via green synthesis using the yeast O. polymorpha, to characterize these gNPs and to study their possible application in biosensorics on 
models of amperometric bioelectrodes based on laccase and alcohol oxidase for assays of phenolic compounds and alcohols, respectively.

\section{Materials and Methods}

\subsection{Reagents}

Chloroauric acid $\left(\mathrm{HAuCl}_{4}\right)$, silver nitrate $\left(\mathrm{AgNO}_{3}\right)$, cobalt (II) sulfate $\left(\mathrm{CoSO}_{4}\right)$, manganese(II) chloride $\left(\mathrm{MnCl}_{2}\right)$, potassium chromate $\left(\mathrm{K}_{2} \mathrm{CrO}_{4}\right)$, palladium (II) chloride $\left(\mathrm{PdCl}_{2}\right)$, chloroplatinic acid $\left(\mathrm{H}_{2} \mathrm{PtCl}_{6}\right)$, neodymium(III) sulfate $\left(\mathrm{Nd}_{2}\left(\mathrm{SO}_{4}\right)_{3}\right)$, sodium ethylenediaminetetraacetate (EDTA), 2,2'-azinobis (3-ethylbenzothiazoline-6-sulfonate) diammonium salt (ABTS), methanol, and all other reagents and solvents used in this work were purchased from Sigma-Aldrich (Steinheim, Germany). All reagents were analytical grade and were used without further purification. Purified medium-size fragments of chitosan from crab shell were obtained as described earlier [57]. All solutions were prepared with ultra-pure water prepared with Milli-Q (Millipore, Molsheim, Germany).

\subsection{Enzymes}

The following enzymes were used in the current research: laccase, EC 1.10.3.2) from Trametes versicolor (Sigma-Aldrich, Steinheim, Germany), horseradish peroxidase (HRP, EC 1.11.1.7) from Armoracia rusticana (Aster, Lviv, Ukraine), and AO (EC 1.1.3.13) from Ogataea (Hansenula) polymorpha C-105 ( $\mathrm{gcr} 1 \mathrm{cat} X)$ purified by us as described earlier [58].

In order to prepare fresh solutions of enzymes, commercial laccase $\left(10 \mathrm{U} \cdot \mathrm{mg}^{-1}\right)$ was dissolved in $20 \mathrm{mM}$ Na-acetate buffer, $\mathrm{pH} 4.5$, up to $200 \mathrm{U} \cdot \mathrm{mL}^{-1}$; commercial HRP $\left(600 \mathrm{U} \cdot \mathrm{mg}^{-1}\right)$ was dissolved in $20 \mathrm{mM}$ phosphate buffer (PB), $\mathrm{pH} 7.0$, up to $400 \mathrm{U} \cdot \mathrm{mL}^{-1}$; $\mathrm{AO}\left(20 \mathrm{U} \cdot \mathrm{mg}^{-1}\right)$ was precipitated by centrifugation $\left(10,000 \mathrm{rpm}, 10 \mathrm{~min},+4{ }^{\circ} \mathrm{C}\right)$ from a $70 \%$ ammonium sulfate suspension in $50 \mathrm{mM} \mathrm{PB}$, $\mathrm{pH} 7.5$, and dissolved in PB up to $50 \mathrm{U} \cdot \mathrm{mL}^{-1}$.

\subsection{Green Synthesis of Nanoparticles}

The recombinant yeast strain O. polymorpha NCYC495-pGAP1-HsARG1 (leu2car1 Sc:LEU2) [59] was used as a tool for the green synthesis of gNPs. The cells were cultivated in Erlenmeyer flasks under aeration in a circular shaker $(200 \mathrm{rpm})$ at $30^{\circ} \mathrm{C}$, for $48 \mathrm{~h}$ as described earlier [56]. The cells were centrifuged at $10,000 \times g$ for $5 \mathrm{~min}$, and the supernatant, i.e., the culture liquid, was used for synthesis of gNPs. For this purpose, the culture liquid was incubated with $0.5 \mathrm{mM}$ solution of the corresponding inorganic salt/acid (see Section 2.1) for up to 5 days at $37^{\circ} \mathrm{C}$. Each experiment was performed in triplicate.

gNP formation was monitored daily, both visually and with UV-visible absorption spectroscopy (Shimadzu UV1650 PC spectrophotometer, Japan). The generated gNPs were also tested using FM and SEM. The resultant gNPs were collected either by centrifugation (using the Eppendorf 5424R centrifuge at $20,000 \times g$ for $1 \mathrm{~h}$ ) followed by homogenization of aggregated gNPs in water, or by the freezing-thawing method [55]. The sample was frozen at $-20{ }^{\circ} \mathrm{C}$ in a narrow upright capillary-like vessel. gNPs were concentrated to the top and to the bottom of the ice-whisker and the fractions of concentrated gNPs were gathered after slow defrosting, and kept at $-20^{\circ} \mathrm{C}$ until used.

\subsection{Characterization of the Synthesized NPS}

Optical UV-visible spectra for characterizing the process of gNP formation from inorganic ions were obtained using a UV1650 PC spectrophotometer (Shimadzu, Kyoto, Japan).

A scanning electron microscope (SEM-microanalyser REMMA-102-02, Sumy, Ukraine) was used for morphological analyses of the samples. The special cover film on the samples with a Butvar solution B-98 (Sigma, St. Louis, MO, USA) in 1.5\% chloroform was formed using an ultrasound method. The distance from the last lens of the microscope to the sample (WD) ranged from $17.1 \mathrm{~mm}$ to $21.7 \mathrm{~mm}$; the accelerator voltage was in the range of 20 to $40 \mathrm{eV}$; zooms were from 2500 to 10,000. 
An inverted fluorescence microscope (FM, Axio Lab. A1., Carl Zeiss, Esslingen, Germany) with excitation by a mercury vapor arc lamp (X-Cite series $120 \mathrm{Q}$ ) was used for sample imaging. The filters set was composed of fluorescein isothiocyanate (green) and 4',6-diamidino-2-phenylindole (blue). In order to prepare the tested sample, a $10 \mu \mathrm{L}$ aliquot of a water-diluted probe was placed on a glass slide and covered with a cover slip (12 mm diameter).

The Infrared spectra of gPdNPs were acquired by a Nexus 470 Thermo-Nicolet FTIR spectrometer (Thermo Fisher Scientific, Dardilly, France) using a single bounce attenuated total reflectance accessory (Spectra-Tech Thunderdome, Thermo Fisher Scientific) with a germanium crystal. Background was systematically recorded before the data acquisition of each sample (spectra from 4000 to $690 \mathrm{~cm}^{-1}$, 256 scans, and resolution $4 \mathrm{~cm}^{-1}$ ). Spectra were obtained after depositing a drop on the crystal and after evaporation of water.

A semi-quantitative express method was used for studying the effect of the synthesized gNPs on alcohol oxidase activity. $10 \mu \mathrm{L}$ aqueous NP solutions were dropped into the cells of a 96-well microplate and supplemented with $10 \mu \mathrm{L}$ chitosan solution $\left(1 \mathrm{mg} \mathrm{mL}^{-1}\right)$ in PB. After 15 min incubation for solid film formation, $15 \mu \mathrm{L}$ AO solution $\left(0.5 \mathrm{U} \mathrm{mL}^{-1}\right)$ in PB were dropped into the cells containing gNPs immobilized in chitosan films. $200 \mu \mathrm{L} o$-dianizidine-based substrate for assay of AO activity were added to each cell, and after 2 min incubation at room temperature, the supernatants were transferred into glass tubes. The cells were washed twice with $200 \mu \mathrm{L} \mathrm{PB}$, and the supernatants were combined with the initial supernatants in glass tubes. $300 \mu \mathrm{L}$ of concentrated $\mathrm{HCl}$ were then added to each tube. As a control, AO solution was put into cells supplemented with chitosan, but without gNPs. AO activity was determined spectrophotometrically [60] and calculated as \% relative to the control sample.

\subsection{Biosensor Evaluation}

\subsubsection{Apparatus}

The amperometric biosensors (ABSs) were evaluated using constant-potential amperometry in a three-electrode configuration with an $\mathrm{Ag} / \mathrm{AgCl} / \mathrm{KCl}(3 \mathrm{M})$ reference electrode, a Pt-wire counter electrode and a working graphite electrode (GE). Graphite rods (type RW001, $3.05 \mathrm{~mm}$ diameter) from Ringsdorff Werke (Bonn, Germany), sealed in glass tubes by means of epoxy glue and used as working electrodes, were polished with emery paper for decreasing their size. Amperometric measurements were carried out using a potentiostat CHI 1200A (IJ Cambria Scientific, Burry Port, UK) connected to a personal computer and performed in a batch mode under continuous stirring in an electrochemical cell with a $20 \mathrm{~mL}$ volume at $25^{\circ} \mathrm{C}$.

\subsubsection{Immobilization of the Enzymes onto Electrodes}

In order to construct the enzyme-based amperometric biosensors, GEs were previously modified by dropping $5 \mu \mathrm{L}$ gPdNPs (or not modified for control electrodes). After formation of solid films, aliquots of a freshly prepared enzyme solution (see Section 2.2) were dropped. A GE with an enzyme only, but without gPdNPs, was used as a control. For construction of the laccase-based ABS, $5 \mu \mathrm{L}$ laccase solution was dropped onto the surfaces of bulk GEs and gPdNPs-modified GEs. For construction of the AO-based ABS, $5 \mu \mathrm{L}$ HRP solution was dropped onto the surface of both GEs (control and modified). After formation of solid films, $7 \mu \mathrm{L}$ of $\mathrm{AO}$ solution were dropped on the electrodes. After drying for $10 \mathrm{~min}$ at room temperature, the layers of enzymes on the electrodes were covered with supporting polymers.

Several fixing methods were tested, including a dialysis membrane, solutions of Nafion, chitosan and polyethyleneimine. The main principle for choosing the most effective covering film was the maximal amperometric output of the bioelectrode on the correspondent substrate and the stability of the bio-recognition layer on the surface of the GE with the enzyme. Experimentally, the best composition was selected: $10 \mu \mathrm{L}$ of the mixture, which contains $1 \%$ chitosan and $0.5 \%$ 
polyethyleneimine solutions $(1: 1, v / v)$, were dropped on the surfaces of laccase- and AO-based electrodes. The prepared bio-functionalized electrodes were rinsed with corresponding buffers (see Section 2.2) and kept in these buffers with $0.1 \mathrm{mM}$ EDTA at $+4{ }^{\circ} \mathrm{C}$ until used. The electrodes were washed with corresponding buffer solutions before and after each measurement in order to stabilize the basic signal.

\subsection{Statistical Analysis}

Statistical analysis of the measurement results and the correlations between the values of the results obtained by different analytical methods was performed using Origin 8.0 and Microsoft Excel.

\section{Results and Discussion}

\subsection{Characterization of the Green-Synthesized Nanoparticles}

Several mono- and bi-metallic gNPs were obtained as a result of the reduction of inorganic salts/acids (see Section 2.1) by the yeast culture liquid (see Section 2.3). Incubation of the reaction mixture (RM) was carried out under the conditions we selected for obtaining gAuNPs [56]. The kinetics of the formation of different gNPs in RM were studied for 5 days visually as well as by UV-Vis. The colors of the different RMs changed after 2 days incubation at $37{ }^{\circ} \mathrm{C}$. Incubation with yeast extracellular metabolites caused the yellow-colored solutions of $0.5 \mathrm{mM} \mathrm{HAuCl} 4, \mathrm{~K}_{2} \mathrm{CrO}_{4}, \mathrm{PdCl}_{2}$ and $\mathrm{H}_{2} \mathrm{PtCl}_{6}$ to change to dark red for gAuNPs, light green for $\mathrm{gCr}_{2} \mathrm{O}_{3} \mathrm{NPs}$, dark green for gPdNPs, and colorless for gPtNPs. The UV-Vis optical spectra of the produced gNPs are presented in Figure 1.

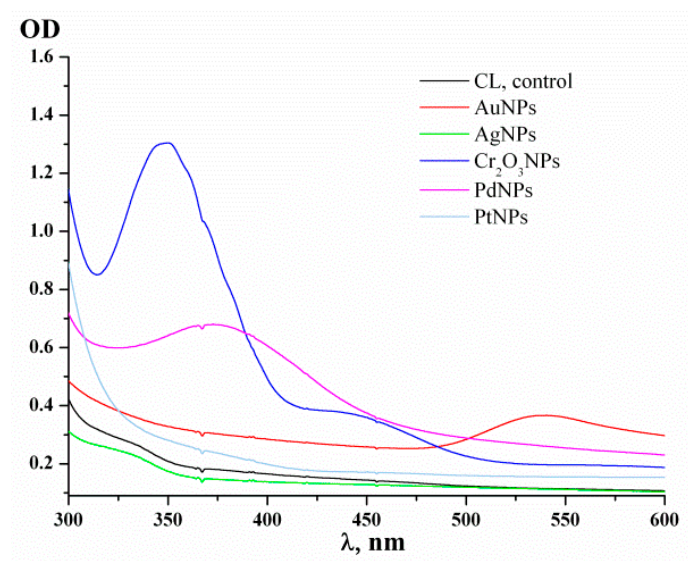

Figure 1. UV-Vis absorption spectra of gNPs synthesized using the culture liquid of a 3-day yeast culture.

The characteristic peaks of the obtained gNPs are identical to the peaks of the plasmon resonance of the described inorganic NPs obtained by chemical synthesis. For example, the spectrum of gPdNPs has a peak at $390 \mathrm{~nm}$ (Figure 1), which is specific for PdNPs [18,61]. A peak of gAuNPs in the range $525-590 \mathrm{~nm}$ is specific for chemically-synthesized AuNPs of different sizes, according to data reported in the literature $[8,12,13,19,38,42,43,48]$ as well as our results $[56,62]$. The color, size and shape of AuNPs and gAuNPs are dependent on the NPs' synthesis conditions: culture liquid of a 1-day culture incubated for 3 days with $\mathrm{HAuCl}_{4}$ produces a dark blue solution of small gAuNPs with a peak at $525 \mathrm{~nm}$. Under the same conditions, a 3-day culture generates a brown-red solution of gAuNPs with a peak at $550 \mathrm{~nm}$ that corresponds to larger AuNPs. The pellet after centrifugation of the last solution looks like a film of pure Au. It was demonstrated that using $1 \mathrm{~L}$ of waste (culture liquid of a 3-day yeast culture) produces approximately $1 \mathrm{mg}$ gAuNPs [56].

Some of the obtained gNPs, namely gAuNPs and gPdNPs, exhibited low toxicity to yeast cells and did not significantly inhibit laccase and $\mathrm{AO}$ when added in moderate concentrations. These gNPs, as prospective carriers for enzyme immobilization, were characterized by scanning electron microscopy 
coupled with X-ray microanalysis (SEM-XRM). Figure 2 demonstrates the overall morphology of the formed particles (triangular, tetrahedral and monodispersed). The XRM data proved the formation of $\mathrm{Au}^{0}$-containing (Figure $2 \mathrm{a}$ ) and $\mathrm{Pd}^{0}$-containing (Figure $2 \mathrm{~b}$ ) products. An AFM study showed that the triangular gAuNPs had an average thickness of $10 \mu \mathrm{m}[56]$.
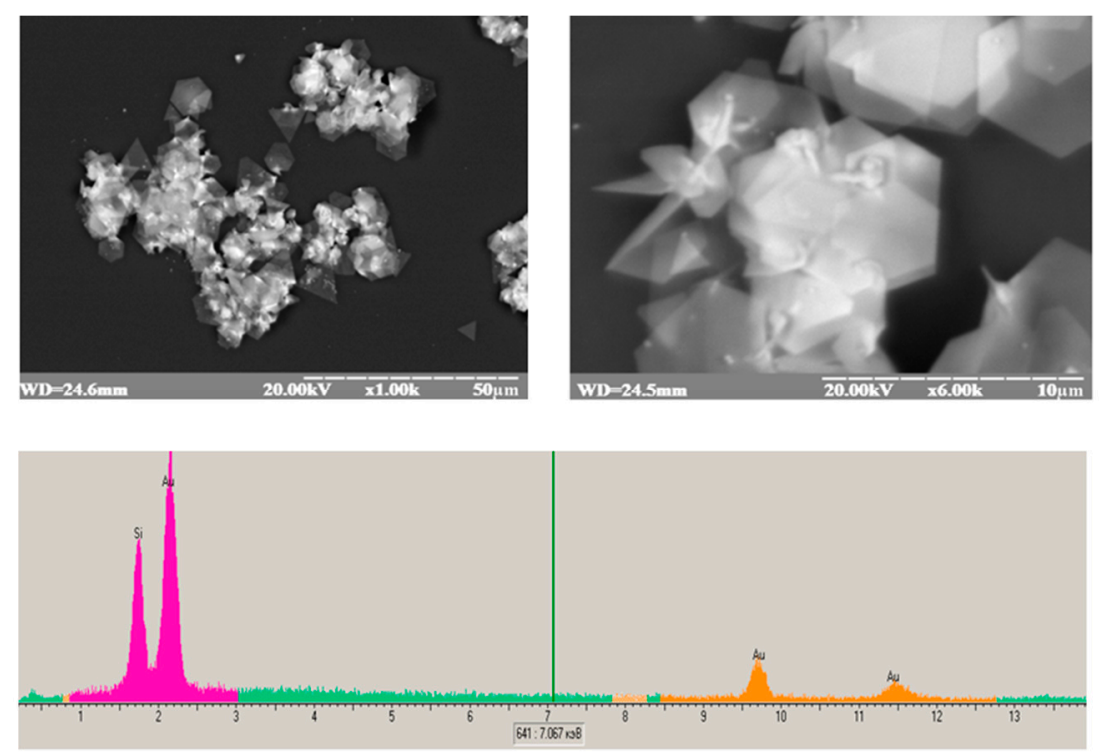

(a)
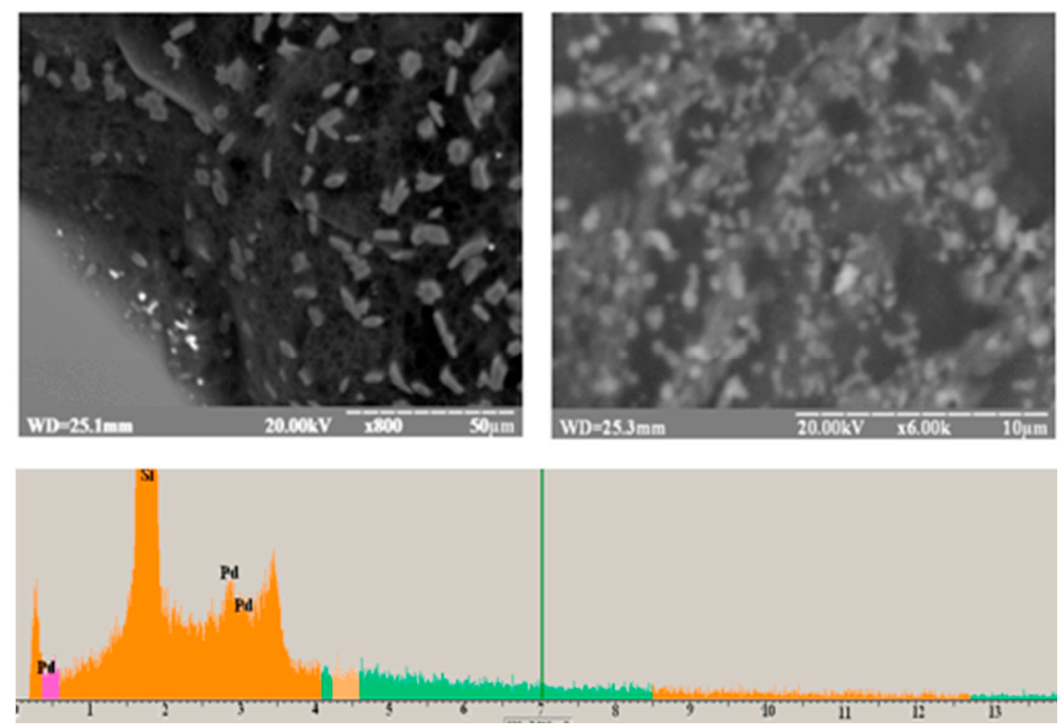

(b)

Figure 2. Characteristics of gNPs synthesized using the culture liquid of 3-day yeast culture: SEM images with X-ray spectral characteristics of (a) gAuNPs and (b) gPdNPs.

GPdNPs were chosen for construction of amperometric biosensors (ABSs) and for further characterization (Figure 3 and Figure SI.1, Supplementary information). The fluorescence images demonstrate that the obtained NPs shine brightly at two filters and emit blue (Figure 3a) and green (Figure $3 b$ ) light. Infrared spectroscopy of the gPdNPs (Figure SI.1) demonstrated that they contained organic compounds (Figure 3c). The large bands centered at 3369, $1645 \mathrm{~cm}^{-1}$ (amide C=O stretching vibration) and $1560 \mathrm{~cm}^{-1}$ (amide C-N stretching and $\mathrm{N}-\mathrm{H}$ bending vibrations) suggest the presence of 
amide groups. The 3369 and $1059 \mathrm{~cm}^{-1}$ bands were assigned to $\mathrm{O}-\mathrm{H}$ stretching and $\mathrm{C}-\mathrm{O}$ stretching modes of the hydroxyl function. Proof for the presence of methyl $\left(-\mathrm{CH}_{3}\right)$ and methylene $\left(-\mathrm{CH}_{2}-\right)$ groups was obtained by absorption peaks at 2963 and $2930 \mathrm{~cm}^{-1}$.

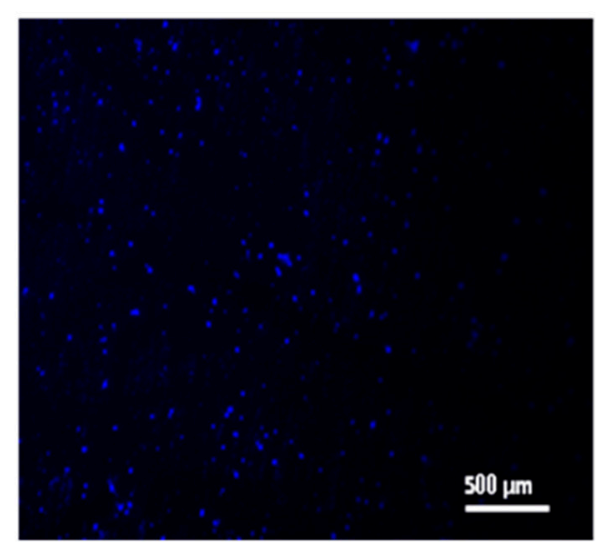

(a)

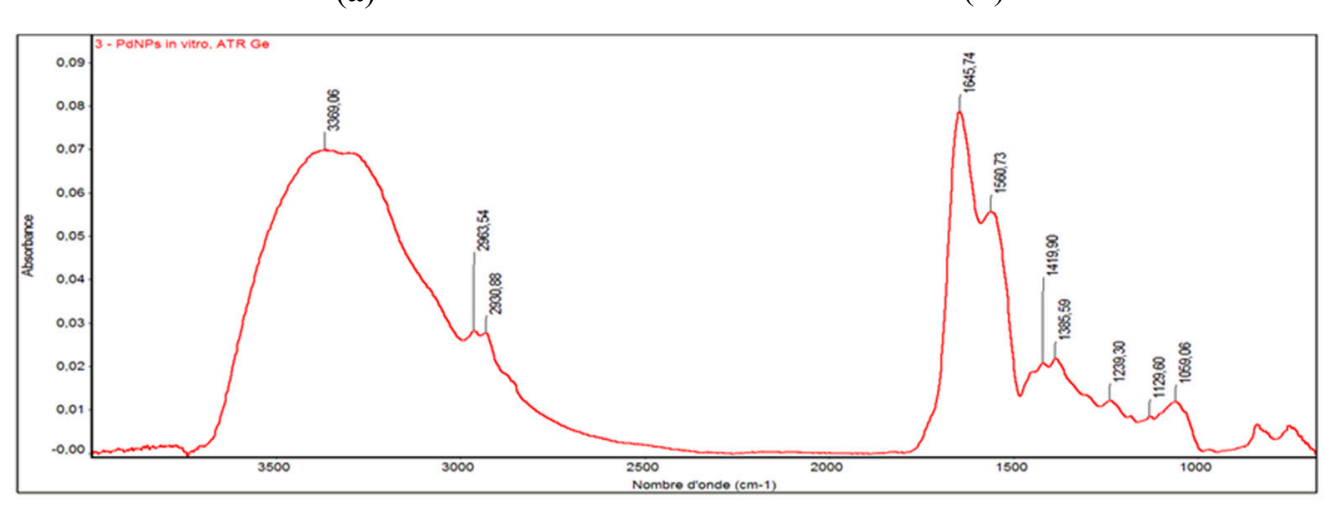

(c)

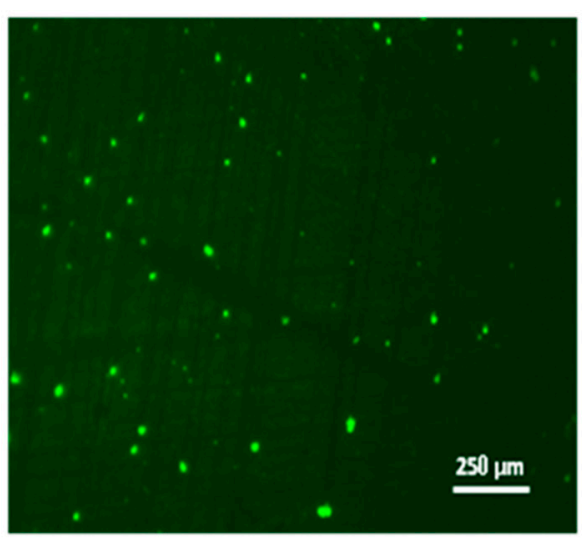

(b)

Figure 3. Characteristics of gPdNPs synthesized using the culture liquid of a 3-day yeast culture: (a) and (b) fluorescence images and (c) FTIR spectra.

The FTIR results proved that the gNPs are products of an interaction of metallic NPs generated in the RM with organic molecules from the culture liquid which contains metabolites of living cells.

\subsection{Biosensor Evaluation}

\subsubsection{Laccase-Based Amperometric Biosensors}

The laboratory prototypes of laccase-based ABSs were developed as described in Section 2.3, including a control electrode (laccase/GE) and a modified one with green-synthesized $\mathrm{Pd}$ (laccase-gPdNPs/GE). Both ABSs were tested using two laccase substrates: bisphenol A (BP) and ABTS.

Figure 4 shows electrochemical characteristics of the laccase-based ABSs, namely chronoamperograms (Figure $4 a$ ) and calibration curves (Figure $4 a, b$ ) of the responses to increasing concentrations of BP, for both bioelectrodes-control (laccase/GE) and modified with green-synthesized Pd (laccase-gPdNPs/GE). According to the graphs presented in Figure $4 \mathrm{~b}$, maximal current responses on BP at substrate saturation $\left(I_{\max }\right)$ and the apparent Michaelis-Menten constant $\left(K_{M}{ }^{a p p}\right)$ to BP as a laccase substrate were estimated for both ABSs. As shown in the calibration curves (Figure 4b), the control ABS has a higher $I_{\max }$ and a 2.5-fold lower $K_{M}{ }^{a p p}$ compared to the modified bioelectrode (laccase-gPdNPs/GE).

Following the obtained chronoamperograms for the ABSs, the calibration curves for BP determination were plotted as illustrated in Figure 4c. The linear ranges for BP determination and sensitivities were calculated for both bioelectrodes. Analytical characteristics of the developed ABSs 
are summarized in Table 1. As shown, the linear range for BP determination is 1.4-fold larger for laccase-gPdNPs/GE than for laccase-GE. The sensitivity of the ABS was calculated, taking the slope (B) of the calibration curve and the surface area of the electrode used $\left(7.3 \mathrm{~mm}^{2}\right)$ into account. As shown in the Table 1, laccase-gPdNPs/GE is 1.7-fold less sensitive to BP than the control ABS.

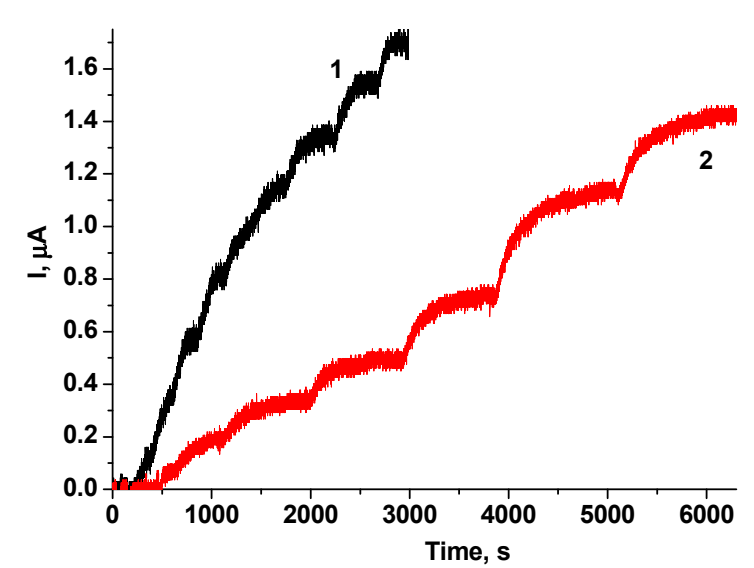

(a)

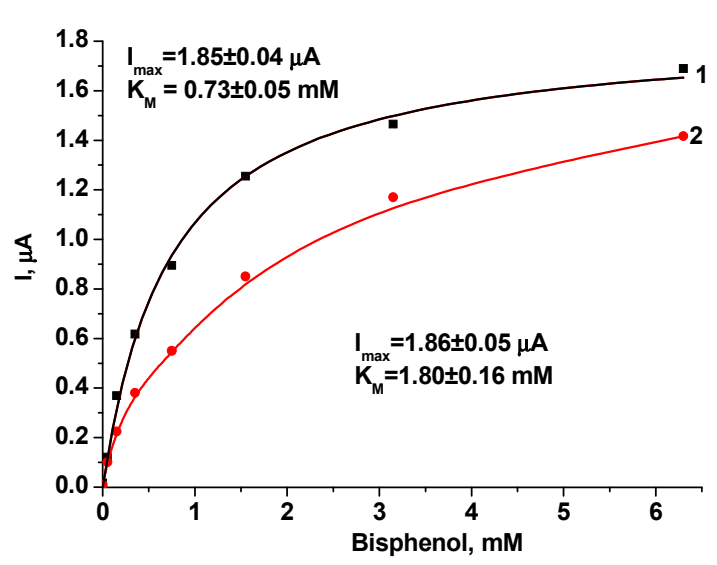

(b)

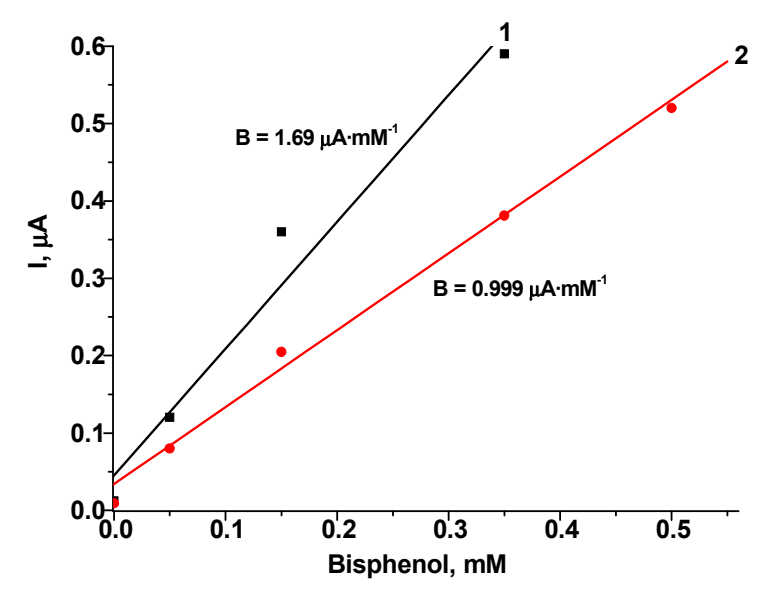

(c)

Figure 4. Chronoamperograms (a), dependence of the amperometric response on increasing concentrations of BP (b) and calibration curves (c) for laccase-based bioelectrodes: control (1) and modified with gPdNPs (2). Conditions: working potential $-100 \mathrm{mV}$ vs. $\mathrm{Ag} / \mathrm{AgCl}$ (reference electrode), $50 \mathrm{mM}$ acetate buffer, $\mathrm{pH} 4.5$.

The developed laccase-based ABSs were tested with another laccase substrate, ABTS, as a non-phenolic redox mediator. Figure 5 presents electrochemical characteristics, namely chronoamperograms of the responses to increasing concentrations of ABTS (Figure 5a) and calibration curves (Figure 5b,c) for the developed laccase-based ABSs. I $\mathrm{max}_{\text {ax }}$ and $K_{M}{ }^{a p p}$ to ABTS were estimated for both ABSs (Figure $5 b$ ). As shown in the calibration curves (Figure $5 b$ ), the control ABS has a 1.3-fold higher $I_{\max }$ and a 1.2-fold lower $K_{M}{ }^{a p p}$ compared to laccase-gPdNPs/GE. It is known from the literature that the $K_{M}$ of ABTS for free laccase from Trametes versicolor in solution is $0.29 \mathrm{mM}$. With the ABS, the $K_{M}{ }^{a p p}$ for ABTS was similar (Table 1). 
Table 1. Analytical characteristics of the developed laccase-based amperometric biosensors.

\begin{tabular}{|c|c|c|c|c|c|c|}
\hline Bioelectrode & Substrate & $K_{M}^{a p p}, \mathrm{mM}$ & $I_{\max }, \mu \mathrm{A}$ & $\begin{array}{l}\text { Linear Range, up } \\
\text { to } \mathrm{mM}\end{array}$ & $\begin{array}{l}\text { Sensitivity, } \\
A \cdot \mathbf{M}^{-1} \cdot \mathbf{m}^{-2}\end{array}$ & $\operatorname{LOD}^{1}, \mathrm{mM}$ \\
\hline Laccase/GE & $\mathrm{BP}$ & $0.73 \pm 0.05$ & $1.85 \pm 0.04$ & 0.35 & 232 & 0.050 \\
\hline Laccase-gPdNPs/GE & $\mathrm{BP}$ & $1.80 \pm 0.16$ & $1.86 \pm 0.05$ & 0.50 & 137 & 0.145 \\
\hline Laccase/GE & ABTS & $0.28 \pm 0.03$ & $19.16 \pm 0.91$ & 0.20 & 5780 & 0.008 \\
\hline Laccase-gPdNPs/GE & ABTS & $0.32 \pm 0.02$ & $14.29 \pm 0.28$ & 0.25 & 3620 & 0.014 \\
\hline
\end{tabular}

${ }^{1}$ LOD—limit of detection.

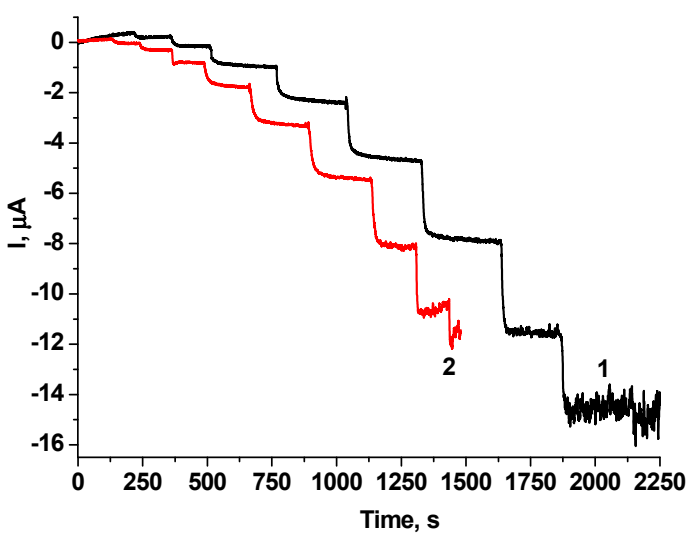

(a)

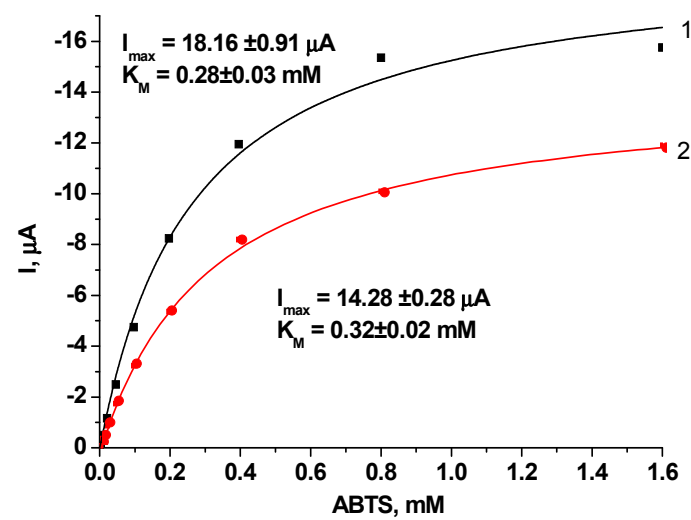

(b)

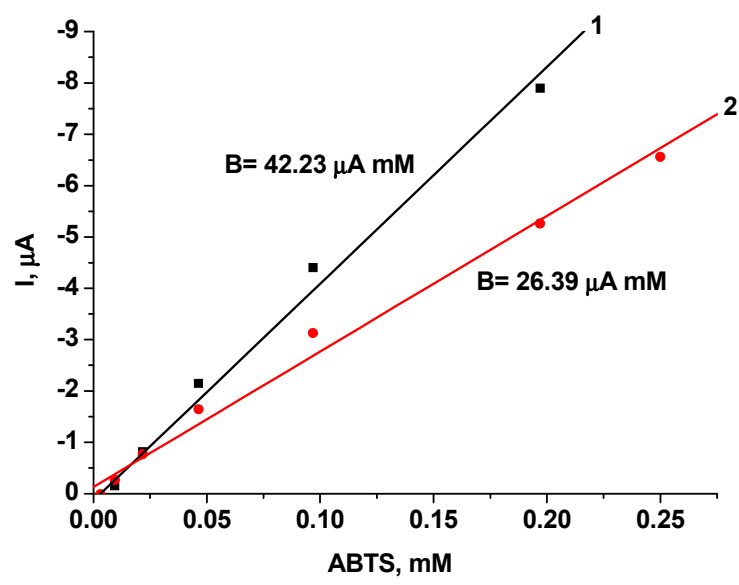

(c)

Figure 5. Chronoamperograms (a), dependence of the amperometric response on increasing concentrations of ABTS (b) and calibration curves (c) for laccase-based GE electrodes: control (1) and modified with gPdNPs (2). Conditions: working potential $-100 \mathrm{mV}$ vs $\mathrm{Ag} / \mathrm{AgCl}$ (reference electrode), $50 \mathrm{mM}$ acetate buffer, $\mathrm{pH} 4.5$.

Following the chronoamperograms, calibration curves for ABTS determination of the developed ABSs were plotted as illustrated in Figure $5 c$. The linear ranges for ABTS determination and sensitivities of both bioelectrodes were calculated. Analytical characteristics of the developed ABSs are summarized in Table 1. Laccase-gPdNPs/GE has a 1.5-fold smaller sensitivity, but a 1.2-fold broader linear range compared to control laccase-GE. Therefore, the tendency of laccase-based-ABSs is as follows: electrode modification with gPdNPs results in lower sensitivity and higher LP for different substrates. 
Numerous biosensors based on laccase from T. versicolor have been constructed [63-70]. Different methods of enzyme immobilization on multi-walled carbon nanotube electrodes were tested $[63,64]$. All tested bioelectrodes were rather sensitive to ABTS, had a limited linear range (up to $0.060 \mathrm{mM}$ ) and a low $\mathrm{I}_{\max }$ (up to $11 \mu \mathrm{A}$ ). Laccase from T. pubescens immobilized on an electrode [66] had a 2-fold higher sensitivity and a similar $K_{M}{ }^{a p p}$ value, but a 2.5-fold lower top of the linear range compared with the currently proposed laccase-gPdNPs/GE (Table 1).

$K_{M}^{a p p}$ values of laccase from T. versicolor immobilized on control or modified graphite electrodes are comparable to the $K_{M}$ of laccases from other fungi [67]. It should be noted that laccase can communicate with the electrode through direct electron transfer, mediated by enzyme substrates. The similarity of the $K_{M}$ obtained for different substrates with free laccases in solutions and immobilized on the electrode surface confirms that the physical binding of the enzyme on electrodes does not have a fundamental effect on the native structure of the enzyme.

\subsubsection{AO-Based ABSs}

$\mathrm{AO}$ is an oxidoreductase with a wide substrate specificity. The enzyme has the highest affinity to methanol (100\%) and is less sensitive to ethanol (50\%), propanol (15\%), formaldehyde (12\%) and butanol (6\%) [71]. We have previously reported the development of bi-enzyme AO/HRP-based ABSs sensitive to primary alcohols [71-75]. AO preparations were isolated from the selected mutant strain O. polymorpha C-105 [75] or mutated AO with a decreased affinity toward substrates [73]. In the current research, we tested the characteristics of bioelectrodes based on yeast $\mathrm{AO}$ and green-synthesized $\mathrm{Pd}$ (AO/HRP-gPdNPs/GE) compared to a control electrode without using NPs-(AO/HRP-GE). Both ABSs were tested on methanol.

Analytes that are structurally similar to methanol, namely ethanol and formaldehyde, also give significant amperometric signals. Figure SI.2 (Supplementary Information) presents the results of the selectivity test for AO/HRP-gPdNPs/GE. It can be seen that the intensity of the amperometric signal of ethanol is $40 \%$ and the signal of formaldehyde is ca. $15 \%$ of the methanol signal. This result is not surprising, in light of the above-mentioned ability of $\mathrm{AO}$ to oxidize these analytes. The results of the stability test for the AO-based bioelectrodes (Figure SI.3, Supplementary information) demonstrate that $\mathrm{AO} / \mathrm{HRP}-\mathrm{gPdNPs} / \mathrm{GE}$ immersed in $50 \mathrm{mM}$ phosphate buffer, $\mathrm{pH}$ 7.5, for 3 days had a higher storage stability than the unmodified graphite electrode with immobilized alcohol oxidase and horseradish peroxidase (AO/HRP/GE).

Figure 6 presents electrochemical characteristics of AO/HRP-based ABSs, namely calibration curves (Figure $6 \mathrm{a}, \mathrm{b}$ ) of responses to increasing methanol concentrations. According to Figure $6 \mathrm{a}$ and Table 2, the control AO-based ABS has 2.9-fold higher $I_{\max }, 1.4$-fold higher $K_{M}{ }^{a p p}$ and 3.7-fold higher sensitivity to methanol compared to the modified bioelectrode. It is worth mentioning that both $K_{M}^{a p p}$ values are higher compared to the $K_{M}$ of $\mathrm{mM}$ in solution $(0.58 \mathrm{mM})$ [58]. The advantages of the constructed AO/HRP-gPdNPs/GE are as follows: a 1.6-fold broader linear range of methanol determination and higher stability than the control ABS. When compared to AO/HRP-EDP/GE [71], $\mathrm{AO} / \mathrm{HRP}-\mathrm{gPdNPs} / \mathrm{GE}$ demonstrates a similar linear range, a lower $I_{\max }$ (25-fold) and lower sensitivity (4.7-fold), but a higher $K_{M}$ app (1.3-fold).

Therefore, in our research we proved the possibility of using gNPs as enzyme carriers for construction of ABSs. It was shown that gNPS-based bioelectrodes, although less sensitive, have a broader linear range and prolonged storage stability compared to control ABSs. The achieved characteristics of these ABSs are desirable for enzymes with analytical importance that have a very high affinity for their substrates, for example laccase and AO. In this case, lower sensitivity is not a critical parameter for the ABSs. Use of gNPs-modified bioelectrodes enables simplifying and increasing the precision of the analytical procedure by avoiding additional dilutions of tested samples. 


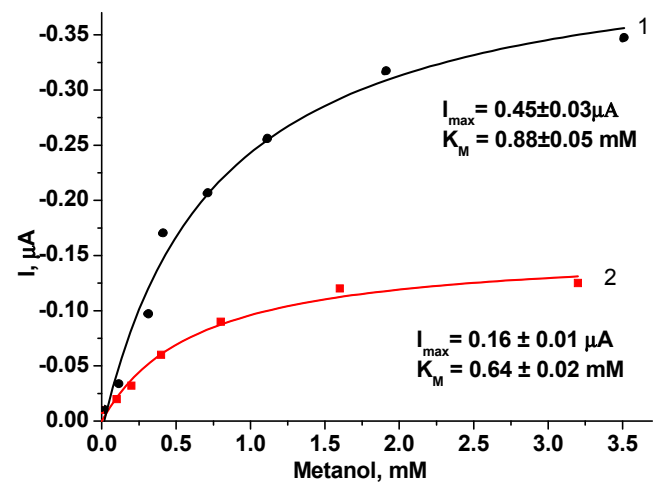

(a)

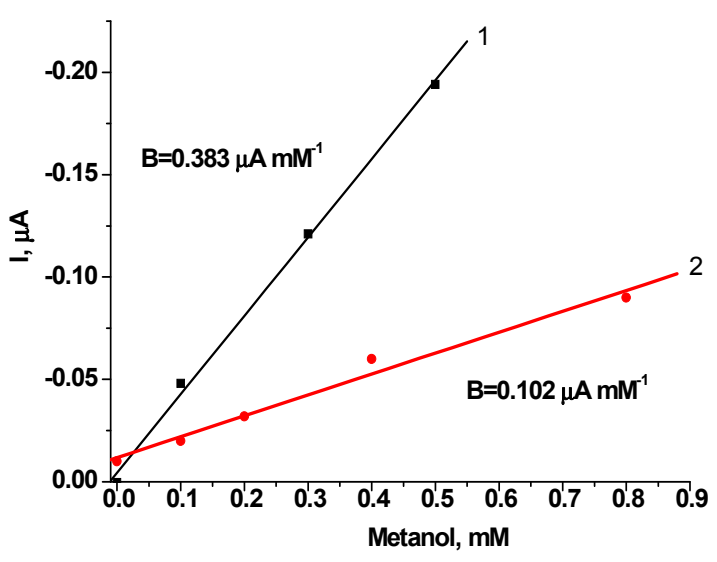

(b)

Figure 6. Graphs of the response as a function of increasing concentrations of methanol (a) and the calibration curves (b) for bioelectrodes: control AO/HRP/GE (1) and graphite electrode, modified by gPdNPs with immobilized alcohol oxidase and horseradish peroxidase AO/HRP-gPdNPs/GE (2). Conditions: working potential $-50 \mathrm{mV}$ vs $\mathrm{Ag} / \mathrm{AgCl}$ (reference electrode), $50 \mathrm{mM}$ phosphate buffer, pH 7.5.

Table 2. Analytical characteristics of the developed methanol-sensitive amperometric biosensors.

\begin{tabular}{|c|c|c|c|c|c|}
\hline Bioelectrode & $K_{M}^{a p p}, \mathbf{m M}$ & $I_{\max }, \mu \mathrm{A}$ & $\begin{array}{c}\text { Linear Range, } \\
\text { up to } \mathrm{mM}\end{array}$ & $\begin{array}{l}\text { Sensitivity, } \\
\mathrm{A} \cdot \mathbf{M}^{-1} \cdot \mathbf{m}^{-2}\end{array}$ & $\mathrm{LOD}^{2}, \mathrm{mM}$ \\
\hline $\mathrm{AO} / \mathrm{HRP} / \mathrm{GE}$ & $0.88 \pm 0.05$ & $0.45 \pm 0.03$ & 0.5 & 52 & 0.005 \\
\hline AO/HRP-gPdNPs/GE & $0.64 \pm 0.02$ & $0.16 \pm 0.01$ & 0.8 & 14 & 0.011 \\
\hline $\mathrm{AO} / \mathrm{HRP}-\mathrm{EDP}{ }^{1} / \mathrm{GE}[71]$ & 0.48 & 4 & 1 & 66 & $\mathrm{ND}^{3}$ \\
\hline
\end{tabular}

${ }^{1}$ EDP—Electrodeposition paint; ${ }^{2}$ LOD—-limit of detection; ${ }^{3} \mathrm{ND}$-ot determined.

\section{Conclusions}

In our research, we demonstrated the possibility of developing reagent-less enzyme-based amperometric biosensors using gNPs. Extracellular metabolites of the thermotolerant yeast Ogataea polymorpha were shown to be a promising cost-effective tool for obtaining gNPs of noble and transition metals. Several gNPs were synthesized and characterized. Yeast AO and fungal laccase were immobilized on the surfaces of graphite electrodes, modified by the most effective enzyme carrier, gPdNPs. Analytical characteristics of the developed bioelectrodes were studied and compared. It was shown that bioelectrodes modified with gPdNPs have lower sensitivities to their substrates, but broader linear ranges of their detection and higher storage stabilities, than unmodified control electrodes. Such bioelectrode characteristics are desirable for enzymes which have a very high sensitivity for their substrates, because before testing, the corresponding samples must be very dilute, which is a problem during on-line control of real samples.

The advantage of the "green" approach is rapid growth of the yeast cells with a high-yield of pure gNPs surrounded by organic compounds that provides the anti-aggregative effect on metallic gNPs. Use of waste yeast cultivation liquid may afford an essential economic effect of green synthesis of NPs, which can be useful as carriers of enzymes and cells in biosensors and biofuel cells.

Supplementary Materials: The following are available online at http://www.mdpi.com/2076-3417/9/4/720/s1.

Author Contributions: Conceptualization: G.Z.G. and N.Y.S.; methodology: N.Y.S.; investigation: O.M.D., R.Y.S., M.D.L. and A.E.; resources: M.V.G.; data curation: G.Z.G. and M.N.; writing—original draft preparation: G.Z.G., O.M.D., and N.Y.S.; writing—review and editing G.Z.G. and M.N.; supervision: M.V.G.; project administration: G.Z.G.; funding acquisition: M.V.G. and M.N.

Funding: This work was partially funded by NAS of Ukraine (The program "Smart sensor devices of a new generation based on modern materials and technologies"), by the Ministry of Education and Science of Ukraine (projects \#0116U004737 and 0118U000297) and by the Research Authority of the Ariel University, Israel. 
Acknowledgments: We acknowledge Mariya F. Ivash (Institute of Cell Biology) for technical support and Oxana M. Zakalska (Institute of Cell Biology) for experimental assistance.

Conflicts of Interest: The authors declare no conflicts of interests.

\section{Abbreviations}

$\begin{array}{ll}\text { NPs } & \text { Nanoparticles } \\ \text { gNPs } & \text { Nanoparticles obtained via green synthesis } \\ \text { gPdNPs } & \text { Pd-based gNPs } \\ \mathrm{gCr}_{2} \mathrm{O}_{3} \mathrm{NPs} & \mathrm{Cr}_{2} \mathrm{O}_{3} \text {-based gNPs } \\ \mathrm{AO} & \text { Alcohol oxidase } \\ \mathrm{HRP} & \text { Horseradish peroxidase } \\ \text { ABS } & \text { Amperometric biosensor } \\ \text { GE } & \text { Graphite electrode } \\ \text { ABTS } & \text { 2,2'-azinobis (3-ethylbenzothiazoline-6-sulfonate) diammonium salt } \\ \text { PB } & \text { Phosphate buffer } \\ \text { SEM } & \text { Scanning electron microscope } \\ \text { SEM-XRM } & \text { Scanning electron microscopy coupled with X-ray microanalysis } \\ \text { FM } & \text { Fluorescence microscope } \\ \text { RM } & \text { Reaction mixture } \\ \text { FTIR } & \text { Fourier transform infrared spectroscopy } \\ \text { BP } & \text { Bisphenol A } \\ K_{M}{ }^{a p p} & \text { Michaelis-Menten constant } \\ I_{m a x} & \text { Maximal current response on tested analyte at substrate saturation }\end{array}$

\section{References}

1. Sastry, M.; Ahmad, A.; Khan, M.I.; Kumar, R. Microbial nanoparticle production. In Nanobiotechnology: Concepts, Applications and Perspectives; Niemeyer, C.M., Mirkin, C.A., Eds.; Wiley-VCH: Weinheim, Germany, 2004; pp. 126-135.

2. Mandal, D.; Mishra, S.; Singh, R.K. Green synthesized nanoparticles as potential nanosensors. In Environmental, Chemical and Medical Sensors; Bhattacharya, S., Agarwal, A.K., Chanda, N., Pandey, A., Sen, A.K., Eds.; Springer: Singapore, 2018; pp. 137-164. ISBN 978-981-10-7750-0.

3. Ali, J.; Zainab, S.; Ali, N. Green synthesis of metal nanoparticles by microorganisms; a current prospective. JNA 2015, 2, 32-38. [CrossRef]

4. Soni, M.; Mehta, P.; Soni, A.; Goswami, G.K. Green nanoparticles: Synthesis and applications. IOSR J. Biotechnol. Biochem. 2018, 4, 78-83. [CrossRef]

5. Naik, G.K.; Mishra, P.M.; Parida, K. Green synthesis of $\mathrm{Au} / \mathrm{TiO}_{2}$ for effective dye degradation in aqueous system. Chem. Eng. J. 2013, 229, 492-497. [CrossRef]

6. Yedurkar, S.M.; Maurya, C.B.; Mahanwar, P.A. Synthesis of nanoparticles by green chemistry process and their application in surface coatings: A review. Arch. Appl. Sci. Res. 2016, 8, 55-69. [CrossRef]

7. Glatstein, D.A.; Bruna, N.; Gallardo-Benavente, C.; Bravo, D.; Pérez, M.E.; Francisca, C.F.M.; Pérez-Donoso, J.M. Arsenic and cadmium bioremediation by antarctic bacteria capable of biosynthesizing CdS fluorescent nanoparticles. J. Environ. Eng. 2018, 144, 04017107. [CrossRef]

8. Mukherjee, P.; Ahmad, A.; Mandal, D.; Senapati, S.; Sainkar, S.R.; Khan, M.I.; Ramani, R.; Parischa, R.; Ajayakumar, P.V.; Alam, M.; et al. Bioreduction of $\mathrm{AuCl}_{4}{ }^{-}$ions by the fungus, Verticillium sp. and surface trapping of the gold nanoparticles formed. Angew. Chem. Int. Ed. 2001, 40, 3585-3588. [CrossRef]

9. Anbazhagan, S.; Azeez, S.; Morukattu, G.; Rajan, R.; Venkatesan, K.; Thangavelu, K.P. Synthesis, characterization and biological applications of mycosynthesized silver nanoparticles. 3 Biotech 2017, 7, 1-9. [CrossRef] [PubMed]

10. Khatami, M.; Alijani, H.Q.; Sharifi, I. Biosynthesis of bimetallic and core-shell nanoparticles: Their biomedical applications. IET Nanobiotechnol. 2018, 12, 879-887. [CrossRef] [PubMed] 
11. Amina, M.; Alarfaj, N.A.; El-Tohamy, M.F.; Al Musayeib, N.M.; Oraby, H.F. Sequential injection-chemiluminescence evaluation of stigmasterol glucoside and luteolin via green synthesis of silver nanoparticles using biomass of Plectranthus asirensis. Green Chem. Lett. Rev. 2018, 11, 523-533. [CrossRef]

12. Aswathy, A.S.; Philip, D. Green synthesis of gold nanoparticles using Trigonella foenum-graecum and its size-dependent catalytic activity. Spectrochim. Acta A 2012, 97, 1-5. [CrossRef]

13. Martinotti, M.G.; Allegrone, G.; Cavallo, M.; Fracchia, L. Biosurfactants. In Sustainable Development in Chemical Engineering Innovative Technologies; Piemonte, V., De Falco, M., Basile, A., Eds.; John Wiley \& Sons, Ltd.: Chichester, UK, 2013; pp. 199-240. ISBN 978-1-509-52363-4.

14. Mandal, D.; Bolander, M.E.; Mukhopadhyay, D.; Sarkar, G.; Mukherjee, P. The use of microorganisms for the formation of metal nanoparticles and their application. Appl. Environ. Microb. 2006, 69, 485-492. [CrossRef] [PubMed]

15. Palomo, J.M.; Filice, M. Biosynthesis of metal nanoparticles: Novel efficient heterogeneous nanocatalysts. Nanomaterials 2016, 6, 84. [CrossRef] [PubMed]

16. Rajan, A.; Meena, K.M.; Philip, D. Shape tailored green synthesis and catalytic properties of gold nanocrystals. Spectrochim. Acta A 2014, 118, 793-799. [CrossRef] [PubMed]

17. Adelere, I.A.; Lateef, A. A novel approach to the green synthesis of metallic nanoparticles: The use of agro-wastes, enzymes, and pigments. Nanotechnol. Rev. 2016, 5, 567-587. [CrossRef]

18. Schlüter, M.; Hentzel, T.; Suarez, C.; Koch, M.; Lorenz, W.G.; Böhm, L.; Düring, R.A.; Koinig, K.A.; Bunge, M. Synthesis of novel palladium( 0 ) nanocatalysts by microorganisms from heavy-metal-influenced high-alpine sites for dehalogenation of polychlorinated dioxins. Chemosphere 2014, 117, 462-470. [CrossRef] [PubMed]

19. Sunkari, S.; Gangapuram, B.R.; Dadigala, R.; Bandi, R.; Alle, M.; Guttena, V. Microwave-irradiated green synthesis of gold nanoparticles for catalytic and anti-bacterial activity. J. Anal. Sci. Technol. 2017, 8, 9. [CrossRef]

20. Kalpana, V.N.; Rajeswari, D. A Review on green synthesis, biomedical applications, and toxicity studies of ZnO NPs. Bioinorg. Chem. Appl. 2018, 2018, 3569758. [CrossRef]

21. Ramesh, C.; Mohan Kumar, K.T.; Latha, N.; Ragunathan, V. Green synthesis of $\mathrm{Cr}_{2} \mathrm{O}_{3}$ nanoparticles using tridax procumbens leaf extract and its antibacterial activity on Escherichia coli. Curr. Nanosci. 2012, 8, 603-607. [CrossRef]

22. Sonker, A.S.; Richa; Pathak, J.; Rajneesh; Kannaujiya, V.K.; Sinha, R.P. Characterization and in vitro antitumor, antibacterial and antifungal activities of green synthesized silver nanoparticles using cell extract of Nostoc sp. strain HKAR-2. Can. J. Biotech. 2017, 1, 26-37. [CrossRef]

23. Ali, S.G.; Ansari, M.A.; Khan, H.M.; Jalal, M.; Mahdi, A.A.; Cameotra, S.S. Antibacterial and antibiofilm potential of green synthesized silver nanoparticles against imipenem resistant clinical isolates of $P$. aeruginosa. Bionanoscience 2018, 8, 544-553. [CrossRef]

24. Owaid, M.N.; Zaidan, T.A.; Muslim, R.F.; Hammood, M.A. Biosynthesis, characterization and cytotoxicity of zinc nanoparticles using Panax ginseng roots, Araliaceae. Acta Pharm. Sci. 2019, 57. [CrossRef]

25. Al-Bahrani, R.M.; Majeed, S.M.A.; Owaid, M.N.; Mohammed, A.B.; Rheem, D.A. Phyto-fabrication, characteristics and anticandidal effects of silver nanoparticles from leaves of Ziziphus mauritiana Lam. Acta Pharm. Sci. 2018, 56, 85-92. [CrossRef]

26. Kharissova, O.V.; Dias, H.V.; Kharisov, B.I. The greener synthesis of nanoparticles. Trends Biotechnol. 2013, 31, 240-248. [CrossRef] [PubMed]

27. Hulkoti, N.I.; Taranath, T.C. Biosynthesis of nanoparticles using microbes-A review. Colloids Surf. B Biointerfaces 2014, 121, 474-483. [CrossRef] [PubMed]

28. Khan, T.; Abbas, S.; Fariq, A.; Yasmin, A. Microbes: nature's cell factories of nanoparticles synthesis. In Exploring the Realms of Nature for Nanosynthesis; Prasad, R., Jha, A., Prasad, K., Eds.; Springer International Publishing: Cham, Switzerland, 2018; pp. 25-50. ISBN 978-3-319-99570-0.

29. Manivasagan, P.; Nam, S.Y.; Oh, J. Marine microorganisms as potential biofactories for synthesis of metallic nanoparticles. Crit. Rev. Microbiol. 2016, 42, 1007-1019. [CrossRef] [PubMed]

30. Lloyd, J.R.; Yong, P.; Macaskie, L.E. Enzymatic recovery of elemental palladium by using sulfate-reducing bacteria. Appl. Environ. Microb. 1998, 64, 4607-4609.

31. Rehman, F.U.; Jiang, H.; Selke, M.; Wang, X. Mammalian cells: A unique scaffold for in situ biosynthesis of metallic nanomaterials and biomedical applications. J. Mater. Chem. B 2018, 6, 6501-6514. [CrossRef] 
32. Wang, C.; Gao, X.; Chen, Z.; Chen, Y.H. Preparation, Characterization and application of polysaccharide-based metallic nanoparticles: A Review. Polymers 2017, 9, 689. [CrossRef]

33. Płaza, G.A.; Chojniak, J.; Banat, I.M. Biosurfactant mediated biosynthesis of selected metallic nanoparticles. Int. J. Mol. Sci. 2014, 15, 13720-13737. [CrossRef]

34. Kaliaraj, G.S.; Bharathiraja, S.; Manivasagan, P.; Kim, S.-K. Green synthesis of metal nanoparticles using seaweed polysaccharides. In Seaweed Polysaccharides: Isolation, Biological and Biomedical Applications; Venkatesan, J., Anil, S., Kim, S.-K., Eds.; Elsevier: Amsterdam, The Netherlands, 2017; pp. 101-109. ISBN 978-0-12-809816-5.

35. Al-Kalifawi, E.J.; Al-Obodi, E.E.; Al-Saadi, T.M. Characterization of $\mathrm{Cr}_{2} \mathrm{O}_{3}$ nanoparticles prepared by using different plant extracts. Acad. J. Agric. Res. 2018, 6, 026-032. [CrossRef]

36. Sone, B.T.; Manikandan, E.; Gurib-Fakim, A.; Maaza, M. Single-phase $\alpha-\mathrm{Cr}_{2} \mathrm{O}_{3}$ nanoparticles' green synthesis using Callistemon viminalis' red flower extract. Green Chem. Lett. Rev. 2016, 9, 85-90. [CrossRef]

37. Kunoh, T.; Shimura, T.; Kasai, T.; Matsumoto, S.; Mahmud, H.; Khayrani, A.C.; Seno, M.; Kunoh, H.; Takada, J. Use of DNA-generated gold nanoparticles to radiosensitize and eradicate radioresistant glioma stem cells. Nanotechnology 2019, 30, 055101. [CrossRef] [PubMed]

38. Krishnan, S.; Narayan, S.; Chadha, A. Whole resting cells vs. cell free extracts of Candida parapsilosis ATCC 7330 for the synthesis of gold nanoparticles. AMB Express 2016, 6, 92. [CrossRef] [PubMed]

39. Mittal, A.K.; Chisti, Y.; Banerjee, U.C. Synthesis of metallic nanoparticles using plant extracts. Biotechnol. Adv. 2013, 31, 346-356. [CrossRef] [PubMed]

40. Deplanche, K.; Caldelari, I.; Mikheenko, I.P.; Sargent, F.; Macaskie, L.E. Involvement of hydrogenases in the formation of highly catalytic $\mathrm{Pd}(0)$ nanoparticles by bioreduction of $\mathrm{Pd}(\mathrm{II})$ using Escherichia coli mutant strains. Microbiology 2010, 156, 2630-2640. [CrossRef] [PubMed]

41. Pantidos, N.; Horsfall, L.E. Biological synthesis of metallic nanoparticles by bacteria, fungi and plants. J. Nanomed. Nanotechnol. 2014, 5, 1000233. [CrossRef]

42. Chinnadayyala, S.R.; Santhosh, M.; Singh, N.K.; Goswami, P. Alcohol oxidase protein mediated in-situ synthesized and stabilized gold nanoparticles for developing amperometric alcohol biosensor. Biosens. Bioelectron. 2015, 69, 155-161. [CrossRef]

43. Vetchinkina, E.P.; Loshchinina, E.A.; Vodolazov, I.R.; Kursky, V.F.; Dykman, L.A.; Nikitina, V.E. Biosynthesis of nanoparticles of metals and metalloids by basidiomycetes. Preparation of gold nanoparticles by using purified fungal phenol oxidases. Appl. Microbiol. Biotechnol. 2017, 101, 1047-1062. [CrossRef]

44. Lin, P.C.; Lin, S.; Wang, P.C.; Sridhar, R. Techniques for physicochemical characterization of nanomaterials. Biotechnol. Adv. 2014, 32, 711-726. [CrossRef]

45. Ramesh, A.; Sundari, M.T.; Thirugnanam, P.E. Microbial molecular mechanisms in biosynthesis of nanoparticles. In Bio-Nanoparticles: Biosynthesis and Sustainable Biotechnological Implications; Singh, O.V., Ed.; John Wiley \& Sons, Inc.: Hoboken, NJ, USA, 2015; pp. 53-81.

46. Chokkareddy, R.; Redhi, G.G. Green synthesis of metal nanoparticles and its reaction mechanisms. In Green Metal Nanoparticles: Synthesis, Characterization and Their Application; Kanchi, S., Ahmed, S., Eds.; Scrivener Publishing LLC: Beverly, MA, USA, 2018; pp. 113-139. ISBN 978-1-119-41887-0.

47. Marslin, G.; Siram, K.; Maqbool, Q.; Selvakesavan, R.K.; Kruszka, D.; Kachlicki, P.; Franklin, G. Secondary metabolites in the green synthesis of metallic nanoparticles. Materials 2018, 11, 940. [CrossRef]

48. Pandey, S.; Oza, G.; Gupta, A.; Shah, R.; Sharon, M. The possible involvement of nitrate reductase from Asparagus racemosus in biosynthesis of gold nanoparticles. Eur. J. Exp. Biol. 2012, 2, 475-483.

49. Lipke, P.N.; Ramsook, C.; Garcia-Sherman, M.C.; Jackson, D.N.; Chan, C.X.J.; Bois, M.; Klotz, S.A. Between amyloids and aggregation lies a connection with strength and adhesion. New J. Sci. 2014, 2014, 815102. [CrossRef] [PubMed]

50. Raveendran, P.; Fu, J.; Wallen, S.L. Completely "green" synthesis and stabilization of metal nanoparticles. J. Am. Chem. Soc. 2003, 125, 13940-13941. [CrossRef] [PubMed]

51. Sagar, S.S.; Naraian, R. Biosynthesis of nanoparticles by penicillium and their medical applications. In New and Future Developments in Microbial Biotechnology and Bioengineering; Gupta, V.G., Rodriguez-Couto, S., Eds.; Elsevier: Amsterdam, The Netherlands, 2018; pp. 235-246.

52. Ksheminska, H.P.; Honchar, T.M.; Gayda, G.Z.; Gonchar, M.V. Extra cellular chromate reducing activity of the yeast cultures. Cent. Eur. J. Biol. 2006, 1, 137-149. [CrossRef] 
53. Ksheminska, H.; Honchar, T.; Usatenko, Y.; Gonchar, M.V. The chromate resistance phenotype of some yeast mutants correlates with a lower level of $\mathrm{Cr}(\mathrm{V})$-species generated in the extra-cellular medium. Biometals 2010, 23, 633-642. [CrossRef] [PubMed]

54. Ksheminska, H.P.; Gayda, G.Z.; Ivash, M.F.; Gonchar, M.V. Chromate-resistant mutants of the yeast Pichia guilliermondii: Selection and properties. Microbiology 2011, 80, 314-325. [CrossRef]

55. Ksheminska, H.P.; Gayda, G.Z.; Ivash, M.F.; Gonchar, M.V. The details of extra-cellular chromate reduction by the yeasts Pichia guilliermondii. First Indep. Sci. J. 2015, 1-2, 18-23.

56. Stasyuk, N.; Gayda, G.; Serkiz, R.; Gonchar, M. The "green" synthesis of gold nanoparticles by the yeast Hansenula polymorpha. Visnyk Lviv. Univ. (Ser. Biol.) 2016, 73, 96-102.

57. Lootsik, M.D.; Bilyy, R.A.; Lutsyk, M.M.; Stoika, R.S. Preparation of chitosan with high blood clotting activity and its hemostatic potential assessment. Biotechnol. Acta 2015, 8, 32-40. [CrossRef]

58. Shleev, S.V.; Shumakovich, G.P.; Nikitina, O.V.; Morozova, O.V.; Pavlishko, H.M.; Gayda, G.Z.; Gonchar, M.V. Purification and characterization of alcohol oxidase from the genetically constructed over-producing strain of the methylotrophic yeast Hansenula polymorpha. Biochemistry (Moscow) 2006, 71, 245-250. [CrossRef]

59. Stasyk, O.V.; Boretsky, Y.R.; Gonchar, M.V.; Sibirny, A.A. Recombinant arginine-degrading enzymes in metabolic anticancer therapy and bioanalytics. Cell Biol. Int. 2015, 39, 246-252. [CrossRef]

60. Gonchar, M.V.; Maidan, M.M.; Pavlishko, H.M.; Sibirny, A.A. A new oxidase-peroxidase kit for ethanol assays in alcoholic beverages. Food Technol. Biotech. 2001, 39, 37-42.

61. Zdansky, K.; Kacerovsky, P.; Zavadil, J.; Lorincik, J.; Fojtik, A. Layers of metal nanoparticles on semiconductors deposited by electrophoresis from solutions with reverse micelles. Nanoscale Res. Lett. 2007, 2, 450-454. [CrossRef]

62. Stasyuk, N.Y.; Gayda, G.Z.; Serkiz, R.J.; Gonchar, M.V. Cell imaging with fluorescent bi-metallic nanoparticles. J. Adv. Chem. 2015, 11, 3499-3511. [CrossRef]

63. Tortolini, C.; Rea, S.; Carota, E.; Cannistraro, S.; Mazzei, F. Influence of the immobilization procedures on the electroanalytical performances of Trametes versicolor laccase based bioelectrode. Microchem. J. 2012, 100, 8-13. [CrossRef]

64. Favero, G.; Fusco, G.; Mazzei, F.; Tasca, F.; Antiochia, R. Electrochemical characterization of graphene and MWCNT screen-printed electrodes modified with AuNPs for laccase biosensor development. Nanomaterials 2015, 5, 1995-2006. [CrossRef] [PubMed]

65. Liu, Y.; Qu, X.; Guo, H.; Chen, H.; Liu, B.; Dong, S. Facile preparation of amperometric laccase biosensor with multifunction based on the matrix of carbon nanotubes-chitosan composite. Biosens. Bioelectron. 2006, 21, 2195-2201. [CrossRef]

66. Gonzalez-Rivera, J.C.; Hindawi, J.F.O. Fabrication of an amperometric flow-injection microfluidic biosensor based on laccase for in situ determination of phenolic compounds. BioMed Res. Int. 2015, 2015, 845261. [CrossRef]

67. Pelle, F.D.; Compagnone, D. Nanomaterial-based sensing and biosensing of phenolic compounds and related antioxidant capacity in food. Sensors 2018, 18, 462. [CrossRef]

68. Jarosz-Wilkołazka, A.; Ruzgas, T.; Gorton, L. Amperometric detection of mono- and diphenols at Cerrena unicolor laccase-modified graphite electrode: Correlation between sensitivity and substrate structure. Talanta 2005, 66, 1219-1224. [CrossRef]

69. Rodríguez-Delgado, M.M.; Alemán-Nava, G.S.; Rodríguez-Delgado, J.-M.; Dieck-Assad, G.; Martínez-Chapa, S.O.; Barceló, D.; Parra, R. Laccase-based biosensors for detection of phenolic compounds. TrAC Trend Anal. Chem. 2015, 74, 21-45. [CrossRef]

70. Mousty, C.; Vieille, L.; Cosnier, S. Laccase immobilization in redox active layered double hydroxides: A reagentless amperometric biosensor. Biosens. Bioelectron. 2007, 22, 1733-1738. [CrossRef] [PubMed]

71. Smutok, O.; Ngounou, B.; Pavlishko, H.; Gayda, G.; Gonchar, M.; Schuhmann, W. A reagentless bienzyme amperometric biosensor based on alcohol oxidase/peroxidase and an Os-complex modified electrodeposition paint. Sens. Actuators B Chem. 2006, 113, 590-598. [CrossRef] 
72. Smutok, O.; Gayda, G.; Dmytruk, K.; Klepach, H.; Nisnevitch, M.; Sibirny, A.; Puchalski, C.; Broda, D.; Schuhmann, W.; Gonchar, M.; et al. Amperometric biosensors for lactate, alcohols, and glycerol assays in clinical diagnostics, In Biosensors_Emerging Materials and Applications; Serra, P.A., Ed.; InTech: Rijeka, Croatia, 2011; pp. 401-446. Available online: https://www.intechopen.com/books/biosensors-emerging-materials-andapplications / amperometric-biosensors-for-lactate-alcohols-and-glycerol-assays-in-clinical-diagnostics (accessed on 20 December 2018).

73. Dmytruk, K.V.; Smutok, O.V.; Ryabova, O.B.; Gayda, G.Z.; Sibirny, V.A.; Schuhmann, W.; Gonchar, M.V.; Sibirny, A.A. Isolation and characterization of mutated alcohol oxidases from the yeast Hansenula polymorpha with decreased affinity toward substrates and their use as selective elements of an amperometric biosensor. BMC Biotechnol. 2007, 7, 33. [CrossRef] [PubMed]

74. Karkovska, M.I.; Stasyuk, N.Y.; Gayda, G.Z.; Smutok, O.V.; Gonchar, M.V. Nanomaterials in construction of biosensors of biomedical purposes. In Multifunctional Nanomaterials for Biology and Medicine: Molecular Design, Synthesis and Application; Stoika, R., Ed.; Naukova Dumka: Kyiv, Ukraine, 2017; pp. 165-177. (In Ukrainian)

75. Gonchar, M.V.; Ksheminska, G.P.; Hladarevska, N.M.; Sibirny, A.A. Catalase-minus mutants of methylotrophic yeast Hansenula polymorpha impaired in regulation of alcohol oxidase synthesis. In Genetics of Respiratory Enzymes in Yeasts; Lachowicz, T.M., Ed.; Wroclaw University Press: Wroclaw, Poland, 1990; pp. 222-228.

(C) 2019 by the authors. Licensee MDPI, Basel, Switzerland. This article is an open access article distributed under the terms and conditions of the Creative Commons Attribution (CC BY) license (http:/ / creativecommons.org/licenses/by/4.0/). 